\title{
The ability of orthodontists and laypeople in the perception of gradual reduction of dentogingival exposure while smiling
}

\author{
Elaine Cristina da Silva Barros', Marielly Damiana Oliveira de Carvalho', \\ Karina Corrêa Flexa Ribeiro Mello², Patrícia Botelho ${ }^{3}$, David Normando ${ }^{4}$
}

\begin{abstract}
Objective: To assess differences in how orthodontists and laypersons perceive a reduction in dentogingival display on smiling. Methods: Sixty examiners from both genders (30 laypersons and 30 orthodontists) evaluated photographs of spontaneous smiles of two subjects, one male and one female. Based on the original images, smile height was modified by means of an image manipulation software program. The examiners assigned scores ranging from 0 to 10, according to the level of pleasantness. Method reproducibility was examined using the Wilcoxon test, while the Friedman and Wilcoxon tests $(p<0.05)$ were employed to observe intra- and interexaminer differences, respectively. Results: No differences were found between the groups of examiners - in terms of esthetics - in response to changes in smile height of both genders. However,men smile had lower acceptability than the women smile. A mild reduction in dentogingival display on smiling ( $2 \mathrm{~mm}$ ) was not perceived by either laypersons or orthodontists ( $>$ > 0.05). Conclusions: women smiles achieved higher scores than men smiles however, samples involving a larger number of subjects in each group are required to ensure whether or not this finding is linked to the subjects gender.
\end{abstract}

Keywords: Esthetic Dentistry. Gingiva. Orthodontics. Smile.

Objetivo: avaliar a diferença na percepção de ortodontistas e leigos quanto à redução da exposição dentogengival no sorriso. Métodos: no total, 60 avaliadores de ambos os sexos (30 leigos e 30 ortodontistas) avaliaram fotografias do sorriso espontâneo de dois indivíduos, um do sexo masculino e um do feminino. A partir das imagens originais, a altura do sorriso foi modificada usando-se um programa de manipulação de imagens. Os examinadores emitiram notas de 0 a 10, conforme o nível de agradabilidade. A reprodutibilidade do método foi examinada através do teste de Wilcoxon, enquanto os testes de Friedman e Wilcoxon $(\mathrm{P}<0,05)$ foram utilizados para observar as diferenças intra e interexaminadores, respectivamente. Resultados: os resultados demonstraram não haver diferença entre os grupos de avaliadores com relação à estética quando a altura de ambos os sorrisos foi modificada. Entretanto, o sorriso do indivíduo do sexo masculino teve menor aceitabilidade do que o sorriso feminino. Uma suave redução na exposição dentogengival no sorriso (2mm) não foi percebida por leigos ou ortodontistas ( $>>0,05)$. Conclusão: o sorriso do indivíduo do sexo feminino recebeu notas mais altas do que o do masculino; entretanto, amostras envolvendo um maior número de indivíduos em cada grupo são necessárias para confirmar se a observação estaria relacionada ao sexo do indivíduo examinado.

Palavras-chave: Estética dentária. Sorriso. Ortodontia.

${ }^{1}$ Graduated in Dentistry, UFPA. Specialist in Orthodontics, EAP/ABO-PA.

${ }^{2}$ Graduated in Dentistry, UFPA. Specialist in Orthodontics and Facial Orthopedics, AP/ ABO-PA. Professor, Specialization Program in Orthodontics, EAP/ABO-PA. MSc student in Radiology, São Leopoldo Mandic University,

${ }^{3}$ Graduated in Dentistry, UFPA. Specialist in Orthodontics and Facial Orthopedics, APCD. MSc student in Orofacial Imagiology, SLM.

${ }^{4}$ Specialist in Orthodontics, PROFIS-USP/Bauru. MSc in Integrated Practice, FOUSP. PhD in Dentistry (Orthodontics), UERJ. Adjunct Professor of Orthodontics, UFPA. Coordinator of the Specialization course in Orthodontics, ABO-PA.

\begin{abstract}
How to cite this article: Barros ECS, Carvalho MDO, Mello KCFR, Botelho P, Normando D. The ability of orthodontists and laypeople in the perception of gradual reduction of dentogingival exposure while smiling. Dental Press J Orthod. 2012 SeptOct;17(5):81-6.

Submitted: December 13, 2010 - Revised and accepted: July 12, 2012

» Patients displayed in this article previously approved the use of their facial and intraoral photographs.

» The authors report no commercial, proprietary, or financial interest in the products or companies described in this article.
\end{abstract}

Contact address: David Normando

Rua Boaventura da Silva, 567, Apto 1201 - ZIP CODE: 66.055-090 - Belém/PA - Brazil E-mail: davidnormando@hotmail.com 


\section{INTRODUCTION}

Concepts underlying face and smile esthetics are often subjective, based more often on author opinion than on the scientific method. ${ }^{1-5}$ Patient self-perception issues are further compounded by the judgment of those with whom they interact. Thus, the concepts of esthetics and beauty are biased by subjectivity and personal impressions, rendering any analysis or interpretation of smile esthetics a daunting challenge in orthodontic practice. ${ }^{6}$

Factors such as culture, socioeconomic status and age may influence how beauty standards arise. Moreover, ongoing changes in these variables require that treatments meet the esthetic pluralism inherent in today's society. ${ }^{4}$ Many studies have been conducted to elucidate the factors involved in the attractiveness of the smile. ${ }^{7-12}$ Laypersons seem capable of identifying the characteristics of an ideal smile. Deviations alert professionals to avoid unnecessary treatment of minor discrepancies that are not recognized by the patient. ${ }^{13}$ Tooth size and visibility as well as upper lip position have been identified as the most important predictive variables in determining smile attractiveness. ${ }^{9}$

Visibility of anterior teeth is determined by the smile line. This line is considered low when less than $75 \%$ of the crowns of these teeth are exposed, a condition found in $30 \%$ to $70 \%$ of men. To be considered high, a smile must show a strip of gum beyond the total length of the crown. High smiles are found in $70 \%$ to $100 \%$ of women. ${ }^{10}$ Analysis of the perception of changes in smile height by increasing dentogingival display demonstrated that orthodontists were able to detect $2 \mathrm{~mm}$ increases while general practitioners and laypersons considered as unattractive changes of $4 \mathrm{~mm}$ or larger. ${ }^{14}$

Another investigation on the esthetic perception of 100 subjects divided into two groups consisting of laypersons and women regarding variations in the amount of upper and lower gingival display showed attractiveness dwindles when gingival display is increased during speech and on smiling. The degree of acceptability reached $1 \mathrm{~mm}$ for maxillary gingival display, and $0 \mathrm{~mm}$ for lower incisors. Women found gingival display more acceptable in both groups while images of women were assigned lower scores by examiners of both genders, implying increased need to achieve better cosmetic results in women. ${ }^{15}$

Although the literature reports that a perfect smile line is one that runs at the gingival margin of maxillary central incisors, ${ }^{11}$ and that the smile gradually loses attractiveness as dentogingival display is increased (high smile), ${ }^{14,15}$ the esthetic impact caused when dentogingival display is decreased (smiling below) has not been evaluated so far.

\section{MATERIAL AND METHODS}

Spontaneous front view photographs of a man and a woman were obtained with a digital camera model Stylus Tough-6000, Olympus (Orlando, USA). The photographer stood at a distance of approximately one meter from the individual (Fig 1 and 2). The photos were then adjusted at different levels of brightness, contrast and cropping, and were manipulated in Adobe Photoshop 7.0 (California, USA) image processing program. Images of crown exposure were backward adjusted from $0 \mathrm{~mm}$ to $-6 \mathrm{~mm}$ exposure in
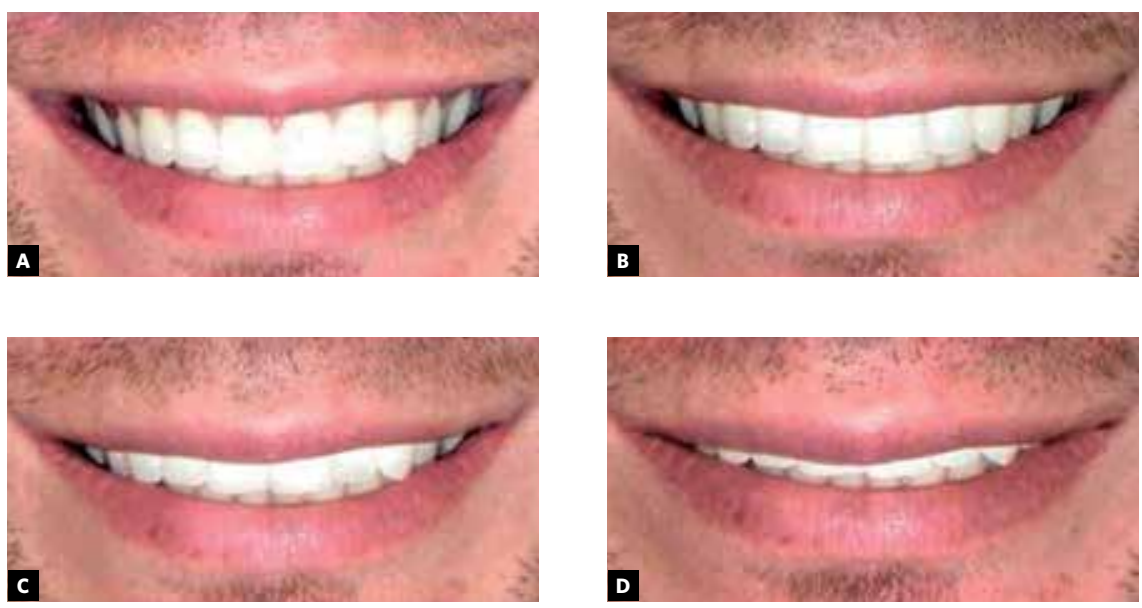

Figure 1 - Masculine spontaneous smile in gingival margin level of: $0 \mathrm{~mm}(\mathbf{A})$, reduction of exposure in $2 \mathrm{~mm}$ (B), $-4 \mathrm{~mm}$ (C) and - $6 \mathrm{~mm}$ (D). 

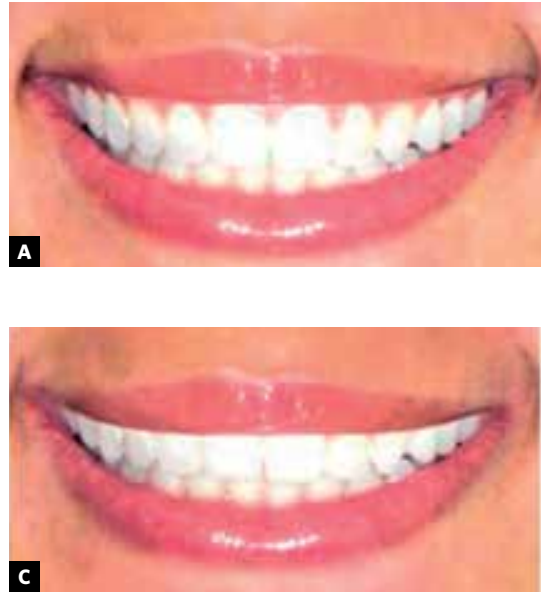
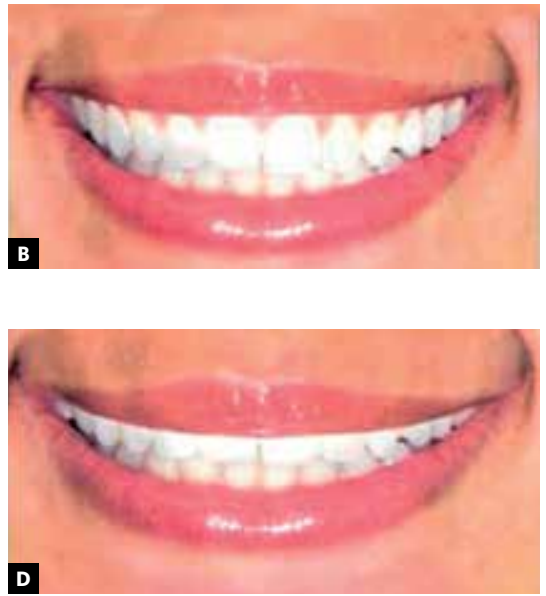

Figure 2 - Feminine spontaneous smile in gingival margin level of: $0 \mathrm{~mm}(\mathbf{A})$, reduction of $-2 \mathrm{~mm}(\mathbf{B}),-4 \mathrm{~mm}(\mathbf{C})$ and $-6 \mathrm{~mm}(\mathbf{D})$.
$-2 \mathrm{~mm}$ steps starting from the gingival margin of the maxillary central incisors, which was established as a reference for the smile line $[\mathrm{Ml}] .^{16}$

Photos of the smile in close-up view were printed on $10 \times 15 \mathrm{~cm}$ photographic paper with an identification on the back to be examined by 30 orthodontists (duly registered with the Regional Council of Dentistry CRO-PA) and 30 laypersons with college degrees (except dentistry), 15 men and 15 women in each group.

Prior to the analysis, the professionals were asked to evaluate the smiles, assigning scores ranging from 0 to 10, according to their personal notion of smile balance. Scores from 0 to 4 were considered esthetically unpleasant, 5 to 7 as esthetically acceptable and 8 to 10 , esthetically pleasing. No other type of information relevant to the study was given to the examiners. The photographs were randomly arranged and each photo was analyzed for up to 1 minute. Examiners were not allowed to review them.

Method reproducibility was tested using the Wilcoxon test based on scores assigned by the examiners to two duplicate photos $-4 \mathrm{~mm}$ reduction for the women and $2 \mathrm{~mm}$ reduction for the men. These duplicates were randomly displayed along with the others. Friedman's analysis of variance was employed to assess the different scores individually assigned to the photographs of both genders by orthodontists and laypersons. Differences in the assessment performed by the two groups of examiners (orthodontists x laypersons) were examined using the Wilcoxon test. Statistical analyzes were performed at $95 \%$ confidence level $(\mathrm{p}<0.05)$.

\section{RESULTS}

Method reproducibility revealed no statistically significant difference between the results obtained for the original picture and its copy, by both examiner groups ( $\mathrm{p}>0.05)$ (Table 1$)$.

Among the orthodontists, no significant differences were observed in the women natural smile (0 $\mathrm{mm})$, nor in the changes that produced less exposure of the dentogingival complex at -2 and $-4 \mathrm{~mm}$ (Fig 3). Nonetheless, the difference was found to be significant when the $6 \mathrm{~mm}$ image was analyzed $(\mathrm{p}<0.05)$, although a slight decrease in the scores assigned to $2 \mathrm{~mm}$ and $4 \mathrm{~mm}$ was noted (Fig 3). Investigation of the men's smiles disclosed statistically significant differences starting from $-4 \mathrm{~mm}$ changes $(\mathrm{p}<0.05)$ (Fig 4).

Laypersons' perception of the female smile showed a similar pattern to that of orthodontists. Assessments of the $-2 \mathrm{~mm}$ and $-4 \mathrm{~mm}$ images were not statistically different from those of the original image $(0 \mathrm{~mm})$. Thus, statistically significant differences were only found in analyzing the $6 \mathrm{~mm}$ image ( $<<0.05$, Fig 4). Analysis of the male patient only yielded statistically significant differences starting at $4 \mathrm{~mm}(\mathrm{p}<0.05)$, consistent with the results found for the orthodontists (Fig 4).

In comparing the scores assigned to female and male smiles in both examiner groups, disregarding other factors that might have had a bearing on these scores, female smiles were found to be more attractive (Figs 3 and 4).

However, comparative analysis of the scores assigned by the groups of examiners - orthodontists 
Table 1 - Median, Interquartile (IQ) deviation and p value (Wilcoxon test) to analyze reproducibility of the images examined by laypersons and orthodontists.

\begin{tabular}{|c|c|c|c|c|c|c|c|c|}
\hline & \multicolumn{2}{|c|}{ Orthodontists } & \multicolumn{2}{|c|}{ Orthodontists } & \multicolumn{2}{|c|}{ Laypersons } & \multicolumn{2}{|c|}{ Laypersons } \\
\hline & $4 \mathrm{~mm}$ (I) & 4 mm (II) & $2 \mathrm{~mm}(\mathrm{I})$ & $2 \mathrm{~mm}$ (II) & $4 \mathrm{~mm}$ (I) & 4 mm (II) & $2 \mathrm{~mm}(\mathrm{l})$ & $2 \mathrm{~mm}$ (II) \\
\hline Median & 7 & 7 & 6 & 6 & 7 & 7.5 & 7 & 6 \\
\hline IQ Deviation & 3 & 1 & 2 & 2 & 2.75 & 3 & 1 & 2 \\
\hline$p$ value & \multicolumn{2}{|c|}{0.3088 (ns) } & \multicolumn{2}{|c|}{0.8767 (ns) } & \multicolumn{2}{|c|}{0.7228 (ns) } & \multicolumn{2}{|c|}{0.3202 (ns) } \\
\hline
\end{tabular}

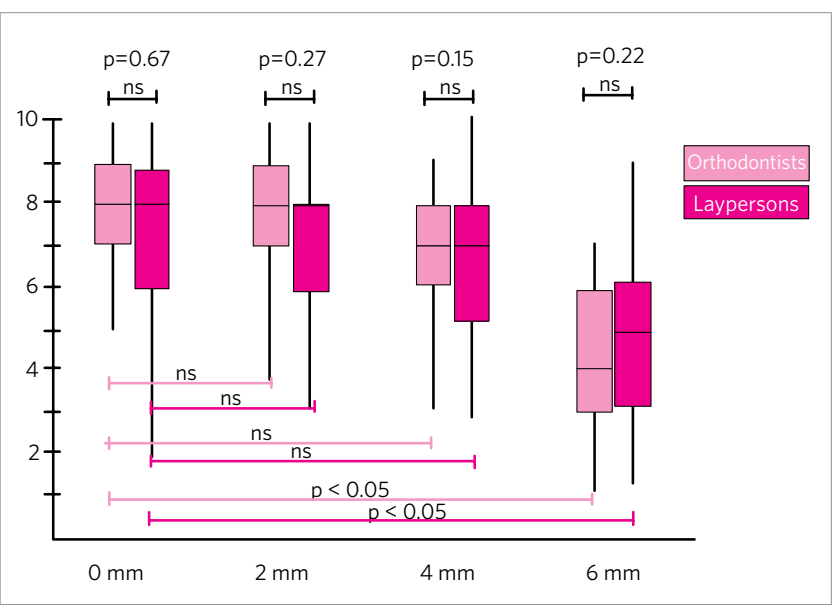

Figure 3 - Assessment of female subject's smile performed by orthodontists (pale pink) and laypersons (dark pink). P values in the upper portion of the chart reflect a comparative analysis between examiner groups (orthodontists $x$ laypersons), whereas $p$ values in the lower portion of the chart depict a comparison between the original image and changes in smile height $(-2,-4$ and $-6 \mathrm{~mm})$.

and laypersons -, showed no statistically significant difference in any of the images assessed (Figs 3 and 4).

\section{DISCUSSION}

Studies have been conducted to determine scientifically the features that characterize an esthetically acceptable smile, and particularly the patient's perception of what features depart from an ideal smile. ${ }^{3,4,11,2,17-20}$

Three important aspects are involved in analyzing smile esthetics, such as, gingival display, curvature formed by the incisal edge of anterior superior teeth and the upper lip, and width of the buccal corridor. ${ }^{18}$ From a strictly orthodontic perspective, dentogingival display and transverse dimension are usually considered the most important factors in smile analysis. ${ }^{7}$ Preference is given to a smile line where the elevation of the upper lip is close to the gingival margin of maxillary incisors. ${ }^{11,15,22,24}$ Thus, the present study was conducted on the assumption

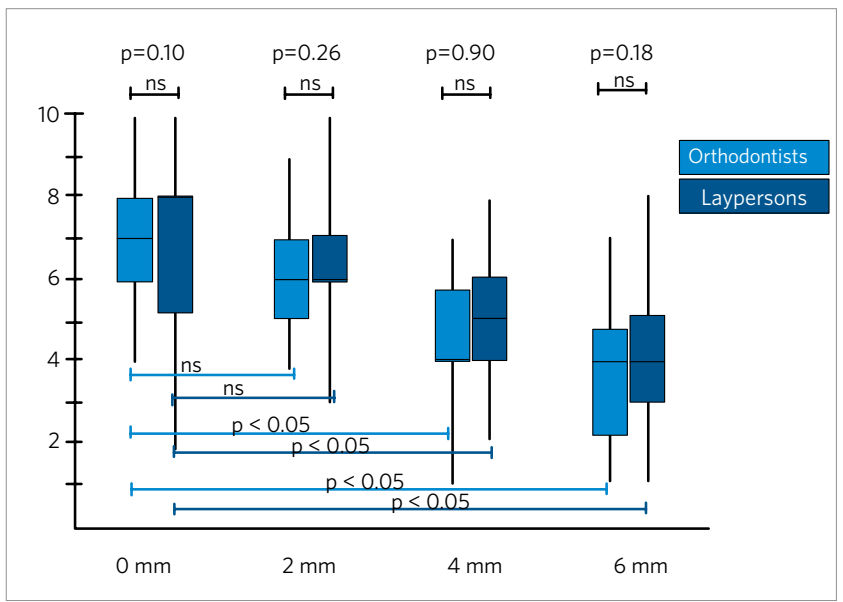

Figure 4 - Assessment of the male subject's smile performed by orthodontists (light blue) and laypersons (dark blue). P values in the upper portion of the chart reflect a comparative analysis between examiner groups (orthodontists $x$ laypersons), whereas $p$ values in the lower portion of the chart depict a comparison between the original image and changes in smile height $(-2,-4$ and $-6 \mathrm{~mm})$.

that the border of the upper lip should be on the same level as the gingival margin $(0 \mathrm{~mm})$.

Firstly, it should be noted that in the present study only close-up photographs of the smile of one male and one female individual were assessed. However, studies in the literature have shown that smile esthetics perception is affected when one looks at the whole face. ${ }^{23}$ Others showed that by capturing the smile with a video camera, anatomical and physiological changes can be better viewed compared to images produced by a digital camera. $^{24,25}$ The methodology employed in this study enables to analyze the entire face since changes in gingival display were performed by lowering the lip, which would become visible on the images taken of the entire face. Besides, the changes simply cannot be recorded on video at this point.

Few studies have assessed the effects of dentogingival display on smiling, and generally aimed to investigate the effects of increased display on the smile. ${ }^{14,15}$ 
In the present study, an attempt was made to determine how many millimeters the crowns of the maxillary incisors would need to be covered by the upper lip in order to compromise the pleasantness of the smile in two individuals - one of each gender - examined by orthodontists and laypersons. The women smile was considered acceptable until $4 \mathrm{~mm}$ of the upper incisor crowns were covered by the upper lip, while the men smile was rated unpleasant at $4 \mathrm{~mm}$ and above (Fig 3 and 4). These findings refute prior reports indicating that low smiles, with no gingival display and partially covered crowns, were more acceptable in men than in women. ${ }^{3,6,22}$ Thus,women smiles would tend to be higher and men's lower, due to a significant difference in the length of the upper lip and height of the maxilla in men..$^{3,6,10,22}$

In this study, the women smiles were assigned higher scores than the men, as depicted in Figures 3 and 4, showing that there was greater attractiveness in the women photographs, which corroborates previous study results. ${ }^{26,21}$ These findings are also in disagreement with results found in women studied by Geron and Athaliah. ${ }^{15}$ When the incisors are not fully visible, a balance between incisal edges and lower lip improves, to a great extent, the appearance of the smile. ${ }^{17}$ Based on this assumption, one could conclude that the lower scores assigned to the men smiles in this study might be related to dental esthetics and/or a less pleasant lip contour, since the men ideal images $(0 \mathrm{~mm})$ were assigned lower scores than the women.

Contemporary dentistry seeks to combine esthetics and function by taking into account not just the professional's views, but above all the patient's opinion. ${ }^{9,13,27}$ In this context, it can be observed that the examiners,, (orthodontists and laypersons), assigned similar scores to the men and women smiles, which demonstrated that their esthetic perception was equivalent, corroborating findings of previous studies. ${ }^{5,27,28}$ Other studies, ${ }^{1,13,14,29}$ however, reported significant differences in assessments by orthodontists

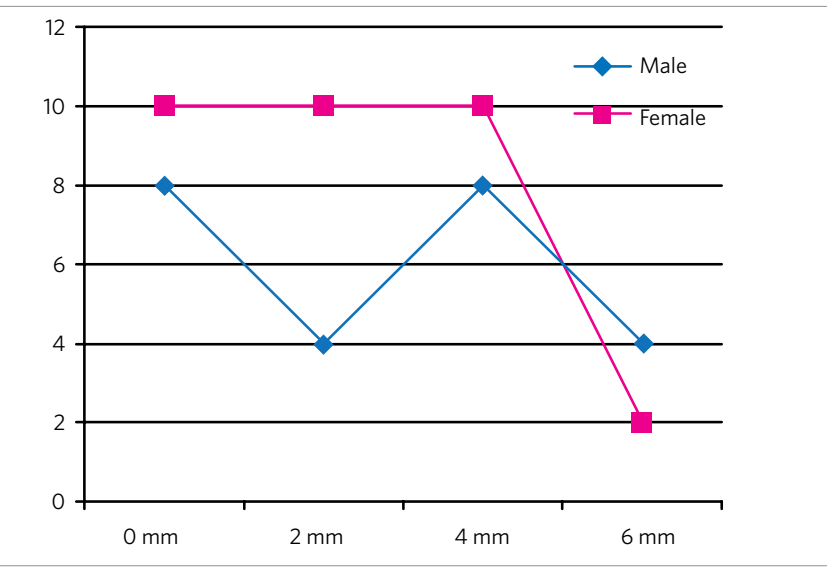

Figure 5 - Self-perception of masculine patients (blue line) and feminine (pink line).

versus laypersons concerning the degree of esthetic demand, with laypersons showing greater tolerance towards most dentogingival changes.

Examiner self-perception remained similar to that of orthodontists and laypersons (Fig 5). The male subject was more demanding of himself, assigning only unpleasantness scores, while the woman was unable to distinguish 0-4 $\mathrm{mm}$ variations, always assigning the same esthetically acceptable scores. This result, although limited by sample size, disagrees with previous studies ${ }^{9}$ which, after analyzing male self-perception, determined that dominance, high self-esteem and greater tolerance are related to behavioral characteristics typical of a man.

\section{CONCLUSIONS}

No differences were found in the esthetic perception of orthodontists versus laypersons in assessing photos of spontaneous smiles with a normal vertical dentogingival display, or smiles with less display. Changes in smile height are perceived differently depending on the gender of the individual being examined. It can therefore be inferred that gender has a bearing on this type of assessment. Nevertheless, further studies involving a larger number of subjects are clearly required. 


\section{REFERENCES}

1. Pinho S, Ciriaco C, Faber J, Lenza M A. Impact of dental asymmetries on the perception of smile esthetics. Am J Orthod Dentofacial Orthop. 2007;132:748-53.

2. PecK S, Peck L. Selected aspects of the art and science of facial esthetics. Semin Orthod. 1995;1:105-26.

3. Tjan AHL, Miller GD, The JGP. Some esthetic factors in a smile. J Prosthet Dent 1984 Jan;51(1):24-8

4. Isiksal E, Hazar S, Akyalçin S. Smile esthetics: Perception and comparison of treated and untreated smiles. Am J Orthod Dentofacial Orthop. 2006;129:8-16.

5. Rosenstiel S F, Pappas M, Pulido M T, Rashid R G. Quantification of the esthetics of dentists' before and after photographs J Dent. 2009;37 Suppl 1:e64-9.

6. Cardoso IL. Desenho estético do sorriso: identificação dos parâmetros de normalidade. Rev Clín Ortodon Dental Press. 2009 Out-Nov;8(5):68-73.

7. Sarver DM. The importance of incisor positioning in the esthetics smile: the smile arc. Am J Orthod Dentofacial Orthop. 2001;120:98-111.

8. Loi H, Nakata S, Counts ML. Effects of buccal corridors on smile esthetics in Japanese. Angle Orthodontist. 2009;79(4):628-33.

9. Van der Geld P, Oosterveld P, Heck G V, Kuijpers-Jagtman A M. Smile attractiveness. Angle Orthod. 2007;77(5):759-65.

10. Peck S, Peck L, Kataja M. The gingival smile line. Angle Orthod. 1999;62(2):91-100 discussion 101-2.

11. Peck S, Peck L, Kataja M. Some vertical lineaments of lip position. Am J Orthod Dentofacial Orthop. 1992;101:519-24.

12. Pagani C, Bottino M C. Proporção áurea e a odontologia estética. J Bras Dent Estet. 2003;2(5):80-5.

13. Ker A J, Chan R, Fields H W, Beck M Rosenstiel S. Esthetics and smile characteristics from the layperson's perspective. JADA 2008; 139(10): 1318-1327.

14. Kokich VO Jr, Kiyak HA, Shapiro PA. Comparing the perception of dentists and lay people to altered dental esthetics. J Esthet Dent. 1999;11:311-24.

15. Geron A, Atalia W. Influence of sex on the perception of oral and smile esthetics with different gingival display and incisal plane inclination. Angle Orthod. 2005;75(5):778-84.

16. Silva NCF, Aquino ERB, Mello KCR, Mattos JNR, Normando D. Habilidade de ortodontistas e leigos na percepção de assimetrias da mandíbula. Dental Press J Orthod. 2011 Ago;16(4):38e1-38E8.
17. Câmara CALP. Estética em ortodontia: diagramas de referências estéticas dentárias (DRED) e faciais (DREF). Rev Clín Ortodon Dental Press. 2006 NovDez;11(6):130-56.

18. Câmara CA. Estética em ortodontia seis linhas horizontais do sorriso. Rev Clín Ortodon Dental Press. 2010 Jan-Feb;15(1):118-31.

19. Bos A, Hoogstraten J, Prahl-Andersen B. Expectations of treatment and satisfaction with dentofacial appearance in orthodontic patients. Am J Orthod Dentofacial Orthop. 2003;123:127-32.

20. Panossian AJ, Block MS. Evaluation of the smile: facial and dental considerations. J Oral Maxillofac Surg. 2010;68:547-54

21. Schabel BJ, McNamara Jr JA, Franchi L, Baccetti T. Q-sort assessment vs visual analog scale in the evaluation of smile esthetics. Am J Orthod Dentofacial Orthop. 2009;135:S61-71.

22. Caetano SRO, Telles CS. Estética do sorriso: relação dos lábios com os dentes e alinha do sorriso. J Bras Ortodon Ortop Facial. 2005;10(58):421-9.

23. Rodrigues CDT, Magnani R, Machado MSC, Oliveira Jr OB. The perception of smile attractiveness. Angle Orthodontist. 2009;79:634-39.

24. Desai S, Upadhyay M, Nanda R. Dynamic smile analysis: Changes with age. Am J Orthod Dentofacial Orthop. 2009;136:310.e1-310.e10

25. Ackerman M B, Brensiger C, Landis R. An evaluation of dynamic lip-tooth characteristics during speech and smile in adolescents. Angle Orthodontist. 2004; $74: 43-50$

26. Hunt $O$, Jonhston $C$, Hepper $P$, Burden $D$, Stevenson $M$. The influence of maxillary gingival exposure on dental attractiveness ratings Eur J Orthod. 2002 Apr;24(2):199-204.

27. Schabel B J, Franchi L, Baccetti T, McNamara Jr J A. Subjective vs objective evaluations of smile esthetics. Am J Orthod Dentofacial Orthop. 2009;135:S72-9.

28. Kokich VO Jr., Kokich VG, Kiyak HA. Perceptions of dental professionals and laypersons to altered dental esthetics: asymmetric and symmetric situations. Am J Orthod Dentofacial Orthop. 2006;130(2):141-51.

29. Peck S. An evaluation of smiles. Angle Orthod. 1993:63(3):190. 